\title{
International Society for Knowledge Organization General Assembly
} Agenda

I am very pleased to invite you to the $14^{\text {th }}$ ISKO General Assembly which will take place the 20th May 2014 at $17: 30$ at the University of Krakow, Poland, at the $13^{\text {th }}$ ISKO Conference. All ISKO members are encouraged to attend both the Conference and the General Assembly. (The Executive Committee will meet a day before with the same topics.) The call for applications for the office of president will be issued in March 2014.

The proposed agenda is as follows:

1. Opening

2. Election of General Assembly Chair and the Secretary

3. Approval of \& Additions to the Agenda

4. Minutes of $13^{\text {th }}$ General Assembly, August 8, 2012, Mysore, India

5. President's Report

6. Secretary/ Treasurer's Report; Auditor's Report; Approval

7. Election Mode

8. Election of President 2014-2018

9. Election of Secretary 2014-2018

10. Election of $2^{\text {nd }}$ Vice President 2014-2018

11. Election of Auditors 2014-2018
12. Reports from Chapters

13. Membership Fees

14. Member Management System, Member communication

15. KO Glossary

16. Dahlberg Library

17. Awards

18. KO Journal Report

19. Other ISKO Publications

20. Report on the ISKO Web

21. Report on the Bibliography (incl. older records)

22. Conference Regulations

23. ISKO International Conference 2016 in Rio, Brasil

24. Information on ISKO International Conferences 2018 and later

25. Other Business and Projects

I look forward very much to seeing as many ISKO members as possible at the 13th International Conference and at this 14th General Assembly in Krakow. (GA participants can bring up to 3 proxies in written form from members who are not present.)

H. Peter Ohly, ISKO President 